* Mestranda em Direito pela Faculdade Meridional (IMED). Graduada em Direito em 2017 pela Faculdade Meridional (IMED). Email: jo.siteneski@hotmail.com

** Pós-Doutora em Direito em 2008 pela Universidade Federal de Santa Catarina (UFSC). Doutora em Direito em 2005 pela Universidade do Vale dos Sinos (UNISINOS). Mestre em Direito em 2000 pela Universidade do Vale dos Sinos (UNISINOS). Especialista em Direito Público em 1998 pela Universidade Regional do Noroeste do Estado do Rio Grande do Sul (UNIJUI). Graduada em Direito em 1992 pela Universidade Regional do Noroeste do Estado do Rio Grande do Sul (UNIJUI). Email: salete.oro. boff@gmail.com

\section{UMA Obra e VÁrios Autores: \\ O Direito Autoral e as " Fan- \\ Fictionals" na CUltura Da ConvergênCIA}

\author{
A Work AND VARIOUS AUTHORS: \\ COPYRIGHT AND "FAN-FICTIONALS" IN \\ The Culture of Convergence
}

\section{Jordana Siteneski do Amaral* Salete Oro Boff**}

Como citar: AMARAL, Jordana Siteneski do; BOFF, Salete Oro. Uma obra e vários autores: o direito autoral e as "fan-fictionals" na cultura da convergência. Scientia Iuris, Londrina, v. 22, n. 1, p.162-189, mar. 2018. DOI: $10.5433 / 2178-8189.2018 v 22 n 1 p 162$. ISSN: $2178-8189$

Resumo: O presente artigo versa sobre os Direitos Autorais inseridos no contexto da "cultura da convergência", analisando em específico, o caso das fan-fictionals. O fenômeno da covergência está com o surgimento de novas ferramentas de comunicação, de informação e a popularização da web. Um dos reflexos deste fenômeno é a cultura participativa, pois as fan-fictionals são narrativas criadas pelos fãs com base em livros, filmes ou outras narrativas pré-existentes, que possuem papel importante no letramento e na participação da produção cultural das sociedades. Contudo, essa prática 
tem gerado embates, como no caso americano, em que os grandes estúdios passaram a proibir as fan-fictionals, sob argumento de violação de direitos autorais. A partir disso, pode-se observar que os Direitos Autorais, dependendo da forma como são concebidos, podem desempenhar tanto um papel de proteção e estímulo às criações intelectuais, quanto representar um óbice à participação, fortalecendo os grandes grupos do entretenimento.

Palavras-Chave: Direito autoral. Fanfictional. Cultura da convergência. Liberdade de expressão.

Abstract: This paper dives into the subject of Copyright law, specifically in the context of "culture of convergence", in order to analyze the genre of "fan fictionals". Convergence is a phenomenon that is the result of growing technological advances in the areas of communication, information and the Internet's popularization. A reflection of this era is our participatory culture, since fan fictionals are narratives created by fans and based on books, films or other pre-existing narratives that play an important role in the literacy and participation of a society's cultural production. However, this genre has generated disputes - e.g. United States of America, where studios are banning it, under the pretext of copyright infringement. In light of this, Copyright can be seen in two ways, which varies depending on how they were 
conceived: through a protective lens, which represents an obstacle for participation, evidently strengthening entertainment groups or a creative lens that stimulates new creations.

Keywords: Copyright. Fan-fictional. Culture of convergence. Freedom of expression. 


\section{INTRODUÇÃO}

A temática do presente trabalho versa sobre os direitos autorais inseridos em um contexto permeado por novas tendências e fenômenos envolvendo as mídias e o cenário da comunicação em escala global. Uma dessas tendências aponta para a transformação nos centros de produção dos bens simbólicos e culturais da sociedade, de maneira que os papéis exercidos entre um produtor e um receptor, está sendo reformulada, passando o receptor a ser visto além de uma figura somente passiva.

Este fenômeno denomina-se "cultura da convergência" e está relacionado, em sua origem, com o surgimento de novas ferramentas de comunicação, informação e a popularização da web. Possui três pontos principais: convergência dos meios de comunicação; a cultura participativa e a inteligência coletiva.

A análise deste artigo aborda o segundo reflexo em específico, a "cultura participativa", considerando que as tecnologias propiciaram um aumento nas possibilidades participação dos indivíduos na produção cultural que une enquanto sociedade. Nesse contexto, há que se questionar como os Direitos Autorais são percebidos e se subsistirão a estas transformações. Partindo deste questionamento, e analisando o caso das fan-fictionals em específico, o presente estudo vale-se do método dedutivo e da técnica de pesquisa bibliográficas em fontes secundárias.

A abordagem será dividida em três partes. Na primeira, o objetivo é realizar uma contextualização histórica dos direitos autorais, uma vez que seu surgimento está relacionado com a própria evolução da tecnologia, como se verá. No segundo item, o objetivo é compreender o conceito da fan-fictional e a sua importância na sociedade atual. No terceiro item, analisar-se como ela está sendo vista sob o aspecto dos 
direitos autorais, sobretudo no caso americano. Ao final, abre-se espaço para as considerações finais, de maneira a elucidar os resultados obtidos com a pesquisa, esclarecendo seus limites e possibilidades.

\section{NOTAS INTRODUTÓRIAS DO DIREITO AUTORAL}

O ser humano é em sua essência, um ser criativo, capaz de expressar e exteriorizar suas ideias por meio de suas criações. Destarte, a tutela extensa do direito de autor só é justificada pela criatividade. Se não houver uma base de criatividade, a produção não pode reclamar a proteção do Direito de Autor (ASCENSÃO, 1997, p. 3).

Presentes em todas as atividades criativas, nas manifestações artísticas, culturais, científicas e publicitárias, os Direitos Autorais constituem um ramo da ciência jurídica, que desde seu surgimento, geram controvérsias e precisam lidar com as dificuldades oriundas da imaterialidade de seu objeto: a propriedade intelectual (GANDELMAN, 2001, p. 28).

Em que pese a atividade criativa seja praticada desde os primórdios da humanidade ${ }^{1}$, a previsão jurídica da proteção do autor é algo recente na civilização. Os primeiros marcos regulatórios reportam ao contexto Europeu na Idade Moderna (ZANINI, 2015, p. 27).

Isto se deve ao fato de que na Antiguidade e em parte da Idade Média, as obras literárias e a comunicação eram realizadas em um primeiro momento, através da oralidade, dos gestos, e expressões corporais, passando depois para a escrita. Contudo, a reprodução da obra escrita era feita de forma manual, através dos "copistas" que eram

1 "O poder criativo do homem acompanha a sua evolução. Na antiguidade, constatavam-se as mais diversas formas de manifestação, sem, entretanto, ter formas de garantia dos direitos dos criadores. Acentua-se o maior reconhecimento das atividades intelectuais a partir da Idade Média" (PIRES; BOFF, 2011, p. 93) 
pagos para fazerem esta tarefa. Os autores, nada recebiam, pois a ideia que se tinha era que os copistas, como criadores artísticos deveriam ser remunerados (GANDELMAN, 2001, p. 28-29).

Com o advento da Era Moderna um fato que teve muita importância para o desenvolvimento dos direitos autorais foi o surgimento da imprensa, juntamente com a Revolução Industrial, os quais impulsionaram o mercado e a facilidade de publicação e divulgação das obras (PIRES; BOFF, 2011, p. 94). Antes do desenvolvimento da prensa, toda a produção de livros era centrada na figura dos "monges copistas", onde a única forma de reprodução era por meio de cópias manuscritas (THOMPSON, 2005, p. 56).

O desenvolvimento da prensa levou ao controle sobre a reprodução da obra que era centralizado na figura dos copistas foi mitigado. Em razão da rapidez, facilidade da impressão, e disseminação das obras, cresceu também um número maior de incidência de plágios e contrafação (ZANINI, 2015, p. 42). Os reflexos do advento da imprensa repercutiram na sociedade de diversas maneiras, ensejando uma verdadeira transformação no substrato social, com uma reestruturação nas bases de produção de bens simbólicos e consequentemente, das próprias estruturas de poder (THOMPSON, 2005, p. 56).

Os primórdios de uma legislação sobre direitos autorais remete à Grã-Bretanha de 1710. Considera-se como primeira proteção legal do Direito de Autor o Estatuto da Rainha Ana, oriundo do Parlamento inglês. O Estatuto reconhece os direitos de cópia do autor, dando origem ao termo copyright que é utilizado até os dias de hoje. O autor assume o papel de proprietário do seu trabalho criativo, dispondo sobre a utilização do

2 Para maior aprofundamento, veja-se "A evolução histórica do Direito de Autor”, de Cristiane Epple et al. (2011, p. 9). 
direito patrimonial de sua obra, por um período de 21 anos e determinando que as cópias da obra, nesse lapso temporal, deveriam ser autorizadas pelo criador por meio de contrato (EPPE et al., 2011, p. 18).

Portanto, a gênese dos direitos autorais encontram-se em duas "tradições", surgidos na Inglaterra com o instituto do copyright, e o droit d'auteur francês, ligados ao desenvolvimento da impressão, de seu controle por parte do Estado e do surgimento do comércio de livros. Neste sentido, o objetivo principal do copyright não era necessariamente proteger os direitos do autor, mas sim de "regular o comércio do livro", e destituir com um monopólio firmado (MONCAU, 2015, p. 46).

Percebe-se também, que o surgimento dos direitos autorais estão ligados ao início da censura, as lutas pela liberdade de imprensa ${ }^{3}$ e a própria liberdade de expressão. Em 1643 o Parlamento Inglês editou um Ato em que e regulava a impressão de documentos, panfletos e livros, e desta forma, restringia as impressões. Como resposta, John Milton em 1644 escreve seu famoso panfleto, intitulado "Areopagitica" em defesa da liberdade de impressão e de expressão. Os chamados "Licensing Acts" eram editados pelo Parlamento e caracterizavam-se por atos que restringiam a atividade de impressão, que à época, era iminentemente uma ferramenta para o exercício da liberdade de expressão (LIMA, 2012).

$\mathrm{Na}$ origem francesa, os direitos autorais estão relacionados com o contexto pós-Revolução de 1789, em que destacam-se dois decretos importantes para o direito autoral: o Decreto 13-19 de janeiro de 1791, que reconheceu o direito dos dramaturgos de exploração sobre a representação de seus trabalhos; e o Decreto de 19-34 de julho de 1793 que reconheceu o direito de reprodução sobre a prioridade literária, musical e artística

3 Liberdade de imprensa significa em sua gênese, "liberdade de imprimir". Neste sentido, se está fazendo referência ao direito de impressão, que não se confunde com a liberdade de expressão. Para mais informações, ver Lima (2012). 


\section{(ZANINI, 2015, p. 54).}

Importante observar aqui, que o direito de autor e o copyright, em que pese sejam muitas vezes tratados como institutos semelhantes possuem divergências. Segundo Gandelman (2001, p. 32-33), o droit d'auteur francês enfoca também os aspectos morais do direito do autor, ou seja, o ineditismo, a paternidade, à integridade da sua obra que não pode ser modificada sem a sua expressa anuência. Mesmo que ele ceda estes diretos a outrem, estes direitos continuam sendo inalienáveis e irrenunciáveis. Esta proteção se estende por toda a vida do autor e depois de sua morte, quando se transferem os direitos para seus herdeiros e sucessores legais.

Há diferenciação de ambos regimes. A fundamentação dos direitos autorais pode ser jusnaturalista, para a qual o direito de autor é um direito natural; ou utilitarista, na qual os monopólios de exploração econômica pelos criadores estimulariam em tese, a criatividade podem ser benéficos à sociedade. Contudo, ambos os regimes foram acolhidos de maneira que se desenvolveu um "hibridismo" nas legislações destas doutrinas. Assim, as doutrinas inglesa e francesa enveredaram-se por caminhos diferentes, fazendo com que os sistemas regulatórios desenvolvessem divergências entre si. Atualmente, com a tendência de harmonização dos sistemas com os sistemas internacionais de proteção, essas diferenças passam a ser menores (MONCAU, 2015, p. 59).

O direito autoral passa a estruturar a proteção jurídica da matéria prima da comunicação entre seres humanos. Essas características oriundas do direito Francês e Inglês influenciaram a formatação do direito autoral nos dias atuais, abrangendo as obras literárias ou artísticas, por exemplo, pintores, escritores, dramaturgos, compositores, escultores e trabalhos profissionais, como criações publicitárias, projetos de arquitetura e outros 
e programas de computador (GANDELMAN, 2001, p. 32-33).

A Lei de Direitos Autorais (LDA) $n^{0}$ 9.610/1998 reservou proteção ao instituto dos direitos conexos, no art. 89, que são os direitos titulados pelos intérpretes, (atores, cantores, regentes, instrumentistas), produtores de fonogramas e empresas de radiodifusão (COELHO, 2012, p. 290). Esta proteção ao intérprete e executante guarda relação com a ideia de que aqueles também seriam criadores intelectuais, de sorte que, deveria ter uma série de direitos protegidos tal como o autor (ASCENSÃO, 1997, p. 463).

Do mesmo modo, a Lei no 9.610/98 (BRASIL, 1998), concebe o direito autoral além de um direito de personalidade. Admite a existência do direito moral (pessoal) e o patrimonial. O primeiro garante ao criador o controle à menção de seu nome da divulgação de sua obra e consequentemente o direito a que esta seja mantida íntegra e não seja alterada salvo seu consentimento, além de resguardar o direto de tirá-la de circulação. E o direito patrimonial busca regular as relações jurídicas da utilização econômica das obras intelectuais. 1) não se protege a ideia, mas somente a forma pela qual ela é exteriorizada; 2 ) à obra sempre se liga um suporte físico, do qual, no entanto é independente como objeto de direito; 3 ) os direitos patrimoniais do autor são temporários, enquanto que os morais se eternizam; 4) os diretos do autor nascem do ato de criação e independem de qualquer registro ou formalidade.

O objeto do direito autoral é proteger as obras intelectuais por sua originalidade (no que tange a sua forma externa, também chamado de corpus mechanicum) ou sua criatividade (referente à sua forma interna, ao corpus mysticum) (GANDELMAN, 2001, p. 38). E, devido à vinculação da obra ao seu autor, o direito autoral possui características lhes são inerentes, que compreendem a sua "irrencunciabilidade, 
extrapatrimonialidade, intransmissibilidade inter vivos e causa mortis, a perpetuidade, o caráter absoluto e a inexpropriabilidade" (ZANINI, 2015, p. 261).

Logo, o sujeito do direito autoral é o próprio autor ou o titular de autoria de obra intelectual, sendo que, o objeto deste direito de autor é "a proteção jurídica legal da própria obra criada e fixada em qualquer suporte físico, ou veículo material." (GANDELMAN, 2001, p. 38). Portanto, os direito de autor nascem com a criação e independem de registro, mas a ideia para ser protegida deve ser exteriorizada e fixada em um suporte, do qual, no entanto é independente como objeto de direito. Os direitos patrimoniais do autor são temporários, enquanto que os morais se estendem por prazo indeterminado.

\section{A PARTICIPAÇÃO DOS FÃS NACULTURA: O FAN-FICTIONAL}

De uma maneira ampla, pode-se caracterizar o fan-fictional como uma produção construída pelos fãs sobre suas obras favoritas. Suas origens remontam a década de 1960, no contexto da explosão da cultura pop americana (SOUZA, 2014, p. 46).

Valendo-se das narrativas midiáticas e ícones da cultura pop preferidos, os fãs tecem as suas próprias histórias e narrativas. Muitas vezes, eles aumentam o enredo, imaginam situações paralelas, criam novos personagens e relações entre os mesmos. Embora, como se disse, esta forma de narrativa exista desde a década de 1960 em versões impressas, foi com as novas tecnologias de comunicação e informação, das mídias digitais e cada vez mais interativas, que elas se expandiram e se consolidaram. Neste sentido, estas ferramentas tecnológicas ofereceram espaços que funcionavam como fóruns de discussão e troca de opiniões, 
e essencialmente, era um local para troca de fan-fictions (BLACK, 2006, p. 172).

As fanfics são resultado das possibilidades oriundas das novas ferramentas e tecnologias, pois elas oferecem novos recursos aos fãs, que por sua vez criam novas narrativas. Estas narrativas podem beber de uma única fonte, ou de várias delas as misturando (CAVALCANTI, 2010, p. 6).

Em sua origem elas estão inseridas no contexto dos fandoms (domínio dos fãs), isto é, articulações dos fãs em torno de produtos artísticos em comum, que geram outros produtos artísticos. Incialmente, as fan-fictions eram associadas sobretudo a narrativas escritas pelos fãs do gênero ficção científica. Neste contexto, destacam-se as produções sobre a série Star Treck. No final da década de 1970, com franquias como Indiana Jones e Star Wars, e seriados televisivos como Dr. Who? Impulsionaram as fan-fictions. Logo, atualmente a fan-fiction não está necessariamente relacionada com obras literárias, mas com diversas formas de produção cultural, que podem ser livros, filmes, games, seriados, quadrinhos e artistas (CAVALCANTI, 2010, p. 3).

No Brasil, um dos sites mais famosos de publicações de fanfictions é "Nyah.com.br", que tem uma ferramenta bastante interessante. O site disponibiliza "aulas de língua portuguesa" para os autores, uma vez que cada um é responsável pela correção e revisão de seus respectivos escritos publicados (CAVALCANTI, 2010, p. 6).

Normalmente, quem escreve as fanfictions não almeja o lucro e comercialização, pois tratar-se de uma atividade eminentemente de declaração e homenagem a obra original. São fruto da criatividade de várias pessoas ao redor do globo, e possuem uma série de implicações que reservam reflexões (CAVALCANTI, 2010). Elas consistem em 
"um apelo constante à integração de elemento de obras variadas e à participação do leitor". Não obstante, elas configuram uma nova forma de contar histórias, onde jovens criam novas identidades para si mesmos e personagens das histórias já existentes, e "retratam valores da sociedade em que se inserem" (CAVALCANTI, 2010, p. 15).

É o diálogo estabelecido entre leitores e autores, atrelados ao caráter veloz dos fluxos de troca de informação na internet "traz novas possibilidades para o aprendizado e letramento." (SOUZA, 2014, p. 3). Com efeito, a comunicação e interatividade que acontece com as fanfics têm uma importância no processo de letramento, pois o mesmo não é algo estanque e individualizado.

Zappone (2008, p. 32), analisando a fanfic no contexto do ciberespaço, argumenta que ela remete um universo ficcional no qual figuram atores tal como numa narrativa, como no suporte impresso. Destarte, ao trazer um universo ficcional, uma fanfic situa-se como uma narrativa literária, uma vez que trata-se uma de "história ou fábula", que sintetiza ou representa situações fáticas ou que permeiam o "imaginário coletivo das comunidades do ciberespaço".

De forma semelhante com Souza (2014) e Henry Jenkins (2008), Zappone (2008, p. 33) considera que as fan-fictions constituem um dos "objetos a partir dos quais se podem efetuar práticas de letramento literário." Neste sentido, como propôs a autora, o letramento literário vai além dos limites da escola, de maneira que passa a ser realizado em diferentes espaços.

Agora que já se compreendeu o conceito da fan-fictional, e a importância que esta forma de narrativa vem representando no contexto atual, passa-se a esboçar como a emergência deste fenômeno vem repercutindo nas relações entre produtores e "consumidores" de conteúdo, 
bem como as questões atinentes aos direitos autorais, sob a égide da "cultura da convergência".

\section{OS DIREITOS AUTORAIS E AS FAN-FICTIONS NA "CULTURA DA CONVERGÊNCIA"}

As novas possibilidades surgidas com as TICs causam várias implicações na proteção dos direitos autorais. Uma delas, é que as divergências entre os regimes de copyright e droit d'auteur apenas se renovaram e intensificaram ao longo do tempo. As convenções da OMPI (Organização Mundial de Propriedade Intelectual) que não constam com a ampla adesão mundial parecem ter colocado a Organização e seus tratados em segundo plano. Esse "esvaziamento" da OMPI, atrelado a questionamentos técnicos e jurídicos sobre os rumos a serem tomados pelos direitos autorais na época das novas tecnologias atreladas às novas ferramentas, recursos e possibilidades, com discussões sobre o suporte material - ou midiático - da obra (ZANINI, 2015, p. 82). Não obstante, observa-se um aumento no acesso as redes digitais e a nova configuração na distribuição dos bens intelectuais. Neste sentido, chama-se a atenção para uma chave neste processo: participação.

Diante deste cenário, passa-se a analisar as questões dos direitos autorais, com especial enfoque ao caso das fan-fictions, na perspectiva de uma tendência observada nas mídias, que está transformando a relação entre produtores e consumidores de conteúdo. Este fenômeno tem como condutor, dois fatores: o surgimento de tecnologias de informação e que possibilitaram uma maior participação das pessoas na produção de conteúdo; e uma nova configuração tecnológica em que estes conteúdos transitam em diferentes suportes midiáticos. 
A convergência de mídias, refere-se à difusão de diferentes conteúdos pelos diferentes sistemas e suportes de mídias, que depende da participação ativa dos "consumidores" de mídia. A convergência como a tendência observada nos meios de comunicação em que os fluxos de produção de conteúdo não acontecem mais em uma perspectiva unidirecional e nem sobre um tipo de plataforma somente:

Por convergência, refiro-me ao fluxo de conteúdos através de múltiplas plataformas de mídia, à cooperação entre múltiplos mercados midiáticos e ao comportamento migratório dos públicos dos meios de comunicação que vão em busca das experiências de entretenimento que desejam (JENKINS, 2009, p. 29).

Em outras palavras, a convergência permite que uma pessoa possa acessar um mesmo conteúdo de informação, por meio de diferentes suportes midiáticos, com as devidas adaptações necessárias, afim de melhor explorar as potencialidades e recursos disponibilizados por determinado suporte de mídia.

Na convergência, a circulação de conteúdos depende de forma substancial, da participação dos consumidores. Com efeito, a compreensão sobre o processo de convergência tecnológica, vai muito além da ideia de que ela deve ser compreendida somente como um processo tecnológico, em que um aparelho reúne múltiplas e diversificadas funções (JENKINS, 2009).

Opera-se uma transformação de ordem cultural e sociológica, na medida em que a convergência deve ser visualizada como "um fenômeno com transformações e implicações sociológicas, culturais e mercadológicas". Pois a convergência não acontece nos dispositivos eletrônicos, por mais sofisticados que sejam ela acontece no "cérebro 
dos consumidores individuais" e nas suas interações sociais, na medida em que ocorre uma transformação cultural, visto que os "consumidores" são incentivados a pesquisar informações pelas conexões realizadas entre conteúdos de mídia dispersos (JENKINS, 2009, p. 29-30).

A convergência representa uma "quebra de paradigma" no cenário comunicacional, pois se antes com a revolução digital pensavase que as "novas mídias" iriam substituir as "antigas mídias", na convergência o que se visualiza é justamente a interação entre as "novas e velhas" mídias, ao invés de substituição. E se na década de 1990, viu-se emergir o fenômeno da "revolução digital", hoje sem dúvida o fenômeno da convergência tomou as rédeas da comunicação (JENKINS, 2009, p. 29-31).

Esta tendência emergente na comunicação vai necessariamente refletir na forma como se lida com a comunicação. A começar pelas próprias indústrias de mídia, na qual a convergência pode representar uma oportunidade para os conglomerados de mídias se expandirem ainda mais, uma vez que os conteúdos que tiverem uma boa aceitação pelo público podem migrar para outros suportes.

Por outro lado, considerando que cada vez mais os receptores (ou "consumidores") deixam a passividade para tornarem-se participantes que interagem dos processos de produção de conteúdo, Jenkins (2009, p. 29-30) visualiza uma nova possiblidade de participação das pessoas nas mídias como um dos reflexos deste fenômeno da convergência tecnológica. Com efeito, a uma "cultura da convergência", em que estas transformações operam-se em meio a três conceitos distintos: convergência dos meios de comunicação, a cultura participativa e a inteligência coletiva.

Com cultura participativa, está-se diante de uma outra 
perspectiva em relação aos meios de comunicação e sobre a noção de passividade da audiência. A ideia consolidada sobre "consumidores e produtores" de mídia como ocupantes de papeis estratificados, deve ser revista. Deve-se considerar os consumidores como participantes que interagem através de um novo conjunto de regras, os quais ainda não se conhece perfeitamente. Contudo, a participação das pessoas não existe de maneira igualitária, pois alguns participantes ainda exercem maior poder que outros. Da mesma forma, alguns "consumidores", possuem mais habilidades para participarem que outros (JENKINS, 2009, p. 30).

As TICs possibilitaram o fenômeno da convergência tecnológica, ao permitir uma comunicação e troca de informação mais rápida, bem como realizar múltiplas funções em um mesmo aparelho. Por meio de sistemas de compatibilidade e interoperabilidade, as pessoas podem fazer downloads, assistir filmes, ler livros e comparecer à eventos em lugares remotos, tudo em um único aparelho e simultaneamente.

Desse modo, a convergência destes meios impacta na "forma como consumimos estes meios". Os fãs de um seriado, filme ou romance podem fazer capturas de diálogos no vídeo, fazer resenhas e resumos, discutir em fóruns e chats sobre aquela série, criar e divulgar seus próprios filmes na internet, e escrever fan-fictions. Logo, esta nova apresentação do cenário dos meios de comunicação também impacta no próprio padrão de propriedade dos meios de comunicação. Se antes, por exemplo, o foco de Hollywood era somente o cinema, os conglomerados de mídia têm interesse em uma indústria inteira do entretenimento. Neste contexto da 'cultura da convergência' observa Jenkins $(2009$, p. 44) sobre o mundo do entretenimento e da literatura que eles cresceram "se fantasiando de Darth Vader no Halloween, dormindo nos lençóis da Princesa Leia, lutando com sabres de luz feitos de plástico e brincado com bonequinhos 
de Boba Fett." E o mesmo se deu com a Guerra nas Estrelas que se tornou a "lenda" deles, e agora eles estão determinados a reescrevê-la a seu modo.

A paixão, o encanto e fascinação dos fãs pelos universos em que eles submergem fez com que eles fossem os primeiros a se adaptarem às novas tecnologias de mídia. Esta fascinação dos fãs, muitas vezes "inspira novas formas de produção cultural", que vão de figurinos à fanzines e, mais recentemente, ao cinema digital e a literatura criada pelos fãs. Os apreciadores de uma série passam a reivindicar para si, um papel criativo, querendo tornar-se "participante pleno" do processo. A web potencializou este processo, na medida em que confere maior amplitude de visibilidade da cultura, atuando como principal canal de distribuição desta produção de "cultura amadora". A transformação midiática está reafirmando o "direito que as pessoas comuns têm de contribuir ativamente com a sua cultura". Quando os consumidores assumem um papel de controle nas mídias, dá-se espaço para o desenvolvimento de uma "nova cultura vernácula", representa para o autor, algo que incentiva a ampla participação, a criatividade e uma economia baseada em trocas e presentes (JENKINS, 2009, p. 188-189).

Neste contexto, é importante diferenciar interatividade de participação, pois as mesmas não se confundem. A interatividade diz respeito à forma como as novas tecnologias são desenvolvidas para permitirem o feedback do consumidor. Logo, pode-se imaginar diferentes tipos e graus de interatividade conforme o tipo de tecnologia de informação empregado. Por exemplo, a televisão que permite que o televidente troque de canal, e um videogame onde o usuário pode interferir no próprio universo e desenrolar do enredo. As restrições da interatividade são de ordem tecnológica, pois são definidas pelo designer 
e os recursos que este disponibiliza à plataforma (JENKINS, 2009, p. 190).

Já a participação é "moldada pelos protocolos sociais e culturais". Por exemplo, o quanto se pode conversar dentro de uma sala de cinema é algo que é definido muito mais pelos limites de tolerância estabelecidos pelas plateias em seus respectivos contextos sociais e culturais, do que por alguma propriedade inerente ao cinema em si. A participação é "mais ilimitada, menos controlada pelos produtores de mídia e mais controlada pelos consumidores de mídia." (JENKINS, 2009, p. 190).

Mostra desse fenômeno é a cultura e os produtos de mídia que acabam sendo "transformados" pelos fãs, por meio de uma participação coletiva, como no caso da famosa franquia Star Wars. Em um primeiro momento, Hollywood buscou proibir as fan-finctions que se valessem do universo como palco para serem escritas, almejando reafirmar os direitos de propriedade intelectual. Em um segundo momento, vendou os olhos para as narrativas, fingindo não existirem, ao mesmo tempo em que promoveram trabalhos em vídeos dos fãs, mas limitaram o tipo de filme que os mesmos poderiam fazer (JENKINS, 2009, p. 191).

A Lei dos Direitos Autorais do Milênio Digital reescreveu a Lei dos Direitos Autorais dos EUA de modo a abarcar as exigências e pressões dos produtores dos meios de comunicação de massa, em que ele aponta uma série de reflexos desta postura adota pela lei. Mostra-se extremante autoritária, e foi na contramão do fornecimento de incentivos econômicos aos artistas individuais resguardando-os para agrega-los os conglomerados já consolidados. Também, acolheu a ideia de que os direitos autorais devem perdurar por tempo ilimitado, em detrimento da construção de uma "cultura pública" (JENKINS, 2009, p. 194). 
Reconhecendo que, talvez um dos maiores "burladores" de direitos autorais foi Walt Disney, e também um lobista da propriedade intelectual, como esclareceu Jorge Machado (2008, p. 5), interessante observar as palavras de Lawrence Lessig (2002) segundo o qual diante do lobby da indústria do entretenimento, a lei foi escrita para que "ninguém mais pudesse fazer o que a Disney fez com os irmãos Grimm".

Os lobbies das indústrias e corporações foram gradativamente "endurecendo" as leis de direitos autorais. Nesse caso americano, em 1998, o lobby feito pela Walt Disney para evitar que o personagem Mickey Mouse caísse em domínio público, conseguiu que o prazo de duração dos direitos autorais fosse aumentado de 70 para 90 anos, pelo Sonny Bono Act. (MONCAU, 2015, p. 64).

Os estúdios, em uma tentativa de salvaguardar estes direitos autorais, começaram a emitir notificações aos fãs e criadores amadores para que estes os retirassem da internet. Pertinentes as considerações de Jenkins (2009, p. 196), para quem as indústrias desejam que as pessoas "olhem sem tocar", que "comprem sem usar os conteúdos de mídia”. Nesta relação paradoxal, entre os consumidores e produtores de conteúdo, o fã realiza agregando valor a propriedade intelectual não pode ser reconhecido publicamente, caso o estúdio queira resguardar na totalidade e tão somente para si o valor daquela propriedade.

Outro exemplo deste embate, pode ser observado em dois conflitos envolvendo a saga Harry Potter, da escritora J.K. Rowling. No primeiro conflito, houve uma movimentação dos setores conservadores religiosos de direita que tentaram tirar a saga de circulação. $\mathrm{O}$ outro conflito, guarda relação com os direitos autorais. A Warner Bros tentou controlar as "apropriações" dos fãs dos livros da saga, alegando que as mesmas tratavam-se de violações à propriedade intelectual do estúdio 
(JENKINS, 2009, p.235).

Neste contexto, é possível observar que ambas as tentativas conduzem à "luta pelo letramento", no sentido de que ambas são, em seu cerne, uma luta sobre "os direitos que se tem sobre ler e escrever a respeito de mitos culturais essenciais". Ambas ameaçavam o direito de pessoas de participarem do universo de Harry Poter: a primeira pela leitura, a outra pela escrita. Na perspectiva jurídica, a primeira constitui um ato de censura; a outra o exercício de direitos autorais.

O que se seguiu foi que o estúdio, ao adquirir os direitos da obra literária para filmagem, em 2001, começou a procurar em sites possíveis violações de direitos autorais e os retirava do ar até que se avaliasse o que o site estava fazendo com a franquia (JENKINS, 2009, p. 263).

$\mathrm{Na}$ lei americana, até o momento, não se sabe se a fan-fiction se enquadraria na proteção legal do fair use (uso aceitável), porque a lei de direitos autorais não possui uma categoria que verse sobre a expressão criativa amadora. Na definição de fair use, onde deveria ter um fator de "interesse público", o autor observa que a lei trouxe sim um avanço, mas ele não a ponto de atingir um "direito público generalizado à participação cultural”. Sobre a lei americana, Jenkins $(2009$, p. 263) expõe que necessita de uma revisão, considerando as novas tecnologias

4 Jenkins (2009, p. 263) refere-se como letramento, como sendo uma condição que difere da alfabetização somente, pois o primeiro implica em uma aptidão para lidar com diferentes materiais impressos. Dentro do contexto da "cultura da convergência", implica também em manuseio de outras mídias, de maneira que ele fala em "letramento midiático", como uma forma de letramento que abarque as mídias digitais e tecnologicamente convergentes.

5 A doutrina do fair use - "uso aceitável" ou "uso justo" - refere-se a um instituto da lei de direitos autorais americana que prevê algumas exceções para a exclusividade da utilização pelo detentor dos direitos autorias de um material protegido pela lei. Neste sentido, para propósitos "limitados" e "transformadores" como paródias, críticas e comentários, estes podem ser realizados sem a anuência do detentor dos direitos, não configurando violação. Estas exceções são feitas com base em quatro critérios: 1) propósito e o caráter do uso; 2) A natureza do trabalho protegido por direitos autorais; 3. o montante do trabalho que será usado em relação a todo o trabalho protegido por direitos autorais; e 4) $\mathrm{O}$ efeito que o uso teria no mercado ou o valor do trabalho protegido por direitos autorais. (CALIFORNIA STATE UNIVERSITY, 2012, p. 2). 
"que ampliam o espaço de quem pode produzir e circular materiais culturais." Segundo o autor "os juízes sabem o que fazer com pessoas que têm interesses profissionais na produção e distribuição da cultura; mas não sabem o que fazer com amadores, ou pessoas quem eles consideram amadoras".

Percebe-se que os esforços dos grandes conglomerados de mídia, têm se focado no combate à pirataria, em detrimento de assuntos complexos como a fan-fiction. Como consequência, os fãs são seguidamente vistos como "piratas", que "roubam" dos estúdios e não lhes oferecem nada em troca.

Na opinião de Jenkins (2009, p. 264), no contexto americano, a melhor forma de tratar sobre o assunto, seria reescrever a lei de fair use, dando legitimidade à circulação de narrativas alternativas criadas pelos fãs, produzidos sem fins lucrativos. Não se está negando o direito das empresas de resguardarem contra a usurpação de empresas comerciais concorrentes. Mas se está buscando assegurar o direito de participação das pessoas na construção da cultura. Nesse cenário, os fãs estão em desvantagem, porque a maioria não tem conhecimento de seus direitos, e se os conhecem não possuem tantos recursos legais para se defenderem.

Nos sistemas que originaram do direito continental europeu, como o caso brasileiro, não existe a previsões de fair use. Porém, a LDA adotou alguns institutos que funcionam de forma semelhante, através de limitações e exceções ao direito de autor. Um exemplo é o princípio da dicotomia "ideia-expressão", que postula que somente as expressões de uma ideia através de um suporte são protegidas pelo direito autoral. As ideias somente, enquanto não expressadas, não possuem proteção. Tal princípio encontra fundamento legal nos artigos $7^{\circ}$, caput, e $8^{\circ}$, inciso I da LDA na esfera nacional; e no plano internacional no artigo $9^{\circ}$, item 
2 do Acordo TRIPS (MONCAU, 2015, p. 74-75).

A partir destas observações, parece certo que fenômenos sociais, tecnológicos e mercadológicos trazem consigo, uma necessidade de se repensar as formas de tutelar institutos como a propriedade intelectual, neste caso, mais precisamente, os direitos autorais, de maneira à atender uma nova apresentação da realidade. Com efeito, estas saídas precisam ter inerentemente junto à si, a responsabilidade de balancear a participação no desenvolvimento da cultura, da liberdade de expressão e informação, atrelada à proteção da propriedade intelectual.

Embora este não seja o escopo principal desta análise, cabe observar mesmo com o avanço da "participação" na produção da obra, isto não necessariamente implica em uma verdadeira "democratização" na participação. Assim, não há paridade nos fluxos de informação, uma vez existem barreias econômicas, sociais, tecnológicas e de conhecimento na utilização e acesso a estes recursos e ferramentas. Ademais, toda esta "indústria da cultura" e midiática encontra-se em altíssimo grau de concentração ao redor do globo. ${ }^{6}$

Para Moncau (2015, p. 84) os institutos de direitos autorais podem tanto contribuir para concentração da produção de bens culturais em conglomerados, quanto desestimular este processo "de maneira a interferir no livre debate de ideias, provocando distorções no mercado de comunicação e afetando por consequência, o valor-fim da autoderminação democrática que serve de como fundamento da garantia à livre expressão".

Existe uma relação entre a liberdade de expressão e os direitos autorais, de maneira as vezes, estes podem entrar em colisão. $\mathrm{O}$ autor

6 Neste sentido, pode-se citar Jenkins (2009); Manuel Castells (2006); UNESCO (1980); Ayuda (2012); e Comparato (1994), apenas para ilustrar.

SCIENTIA IURIS, Londrina, v.22, n.1, p.162-189, mar.2018 DOI: 110.5433/2178-8189.2018v22n1p162 
constrói uma ideia "mais abrangente" para a liberdade de expressão. Ela deve ser compreendida como um "direito que nos dá a prerrogativa de atuar sobre os símbolos e conceitos que nos rodeiam, transformando a ressignificando o caldo cultural que nos une.". Com efeito, os direitos autorias podem representar um estímulo à liberdade de expressão, ou como "um óbice ao acessos aos insumos de que um diálogo aberto depende" (MONCAU, 2015, p. 121).

Haveria uma disparidade entre a liberdade de expressão dos indivíduos e das corporações. Explicando, o que pode acontece é que os "grandes grupos" é que poderiam ser os detentores dos direitos, pois teriam maior facilidade em adquiri-los e impedir seu uso (negando permissões de uso e cobrando preços altos para licenciamento das obras). Enquanto isto, produtores independentes teriam menores oportunidades de se expressar a partir do caldo cultural já existente, eis que diante das dificuldades em adquirir esses direitos autorais (MONCAU, 2015, p. 87).

Nesta seara, consegue-se observar uma convergência entre Moncau (2015) e Jenkins (2008), no sentido de que, dependendo da forma como os direitos autorais são edificados, eles podem favorecer os grandes grupos em detrimento de outras pessoas.

Outros autores como Zanini (2015, p. 84) por outro lado, observam que diante de mobilizações que pregam o "livre e amplo acesso à cultura e ao conhecimento", no qual os direitos autorais passam a ser vistos como "entraves" a difusão da cultura e do conhecimento. Para o autor, esta bandeira do "amplo e livre acesso" ao bens intelectuais é discutível e precisa ser analisada com cautela, na medida em que a sua substituição gratuita poderia ter como efeito rebote, a diminuição da produção intelectual. 


\section{CONSIDERAÇÕES FINAIS}

A preocupação com a proteção dos direitos de autor amplia-se com evolução nos meios técnicos de reprodução. A popularização da prensa de tipos móveis pode ser vista como um marco histórico de vital importância. Viu-se aperfeiçoamento das tecnologias de informação e comunicação, bem como o surgimento expansão das redes de internet. Destarte, o Direito Autoral também precisa caminhar na direção dos avanços tecnológicos para trazer respostas jurídicas a nova apresentação da realidade.

Uma tendência observada na sociedade aponta para uma a convergência tecnológica e possibilita uma maior participação do público. Com efeito, vem-se observando na sociedade uma reformulação nas relações estabelecidas entre os receptores e os produtores de conteúdos de mídia. Estas relações são reconfiguradas na medida em que os receptores possuem mais ferramentas e possibilidades de participação no processo de produção dos bens culturais e simbólicos. Neste contexto, observa-se a emergência de um fenômeno que tem dimensões sociais, culturais e tecnológicas nomeado por alguns teóricos como "cultura da convergência".

Atentando para esta forma de relacionamento que surge a partir desta nova realidade, buscou-se analisar os Direitos Autorais sob a égide desta tendência observada, como na "cultura participativa", o caso das fan-fictionals, sobretudo no contexto americano.

As fanfics, como se viu, são obras de ficção escritas pelos fãs de um determinado filme, livro, videogame ou artista que se popularizam internet e desempenham um papel importante no letramento "tradicional" e "midiático" - dos jovens, bem como no estímulo à leitura 
e à escrita e representam uma forma de participação na construção da cultura.

Essa prática é renegada pela grande indústria do entretenimento, que entende existir ofensa de direito autorais a prática da escrita e compartilhamento das fan-fictionals. No contexto americano, os grandes estúdios passaram a coibir e reprimir esta prática, visando a proteção desses direitos.

Entretanto, o que se percebe é que a ideia de uma efetiva participação na produção também é relativa, uma vez que se reconhece que não existe igualdade no acesso aos meios de produção de bens simbólicos. Existem barreiras sociais, tecnológicas e de conhecimento ainda a serem rompidas, para se falar em uma "democratização da participação". Outrossim, há uma configuração monopólica da indústria do entretenimento. Neste sentido, os Direitos Autorais podem ser tanto uma ferramenta para contribuir com a participação dos sujeitos na construção de sua cultura, considerando-se o "uso justo" da obra, sem fins lucrativos, como um processo criativo e transformador; ou atuar de forma contrária, fortalecendo e privilegiando os "grandes grupos".

Diante de um cenário que apresenta maiores possibilidades de participação, ao que tudo indica, faz-se necessário pensar em uma forma de equalizar a proteção os Direitos Autorais, sem que se crie um óbice à participação popular no acesso e na construção da cultura. Os autores podem considerar a participação dos fãs como uma forma de prestígio e de divulgação de suas obras. Esse uso deverá sempre indicar a obra original, não interferir na exploração econômica dos direitos patrimoniais do autor, ao contrário constituir-se em meio de estimular a socialização da obra. 


\section{REFERÊNCIAS}

ASCENSÃO, José de Oliveira. Direito autoral. 2. ed. São Paulo: Renovar, 1997.

AYUDA, Fernando Galindo. Democracia, Internet Y Gobernanza: uma concreción. Revista Seqüência, Florianópolis, v. 33, n. 65, 2012.

BLACK, Rebecca W. Language, culture, and identity in online fanfiction. Irvine, USA: University of California, 2006. Disponível em: <http://dx.doi.org/10.5007/2177-7055.2012v33n65p33>. Acesso em: 7 maio 2017.

BRASIL. Lei $\mathbf{n}^{\mathbf{0}}$ 9.610, de 19 de fevereiro de 1998. Altera, atualiza e consolida a legislação sobre direitos autorais e dá outras providências. Disponível em: $<$ http://www.planalto.gov.br/ccivil_03/leis/L9610. htm>. Acesso em: 7 maio 2017.

CALIFORNIA STATE UNIVERSITY. Office of General Consuel the. Handbook of Copyright and Fair Use. 2012. Disponível em: $<$ https://www.calstate.edu/gc/Docs/CopyrightManual.pdf $>$. Acesso em:1 jun. 2017.

CAVALCANTI, Larissa. Leitura nos gêneros digitais: abordando as fanfics. In: SIMPÓSIO HIPERTEXTO E TECNOLOGIAS NA EDUCAÇÃO, 3., Recife, 2010. Anais... Disponível em: $<$ http://nehte.com.br/simposio/ anais/Anais-Hipertexto-2010/Larissa-Cavalcanti.pdf $>$ Acesso em: 1 jun. 2017.

COELHO, Fábio Ulhoa. Curso de direito civil: direito das coisas e direito autoral. 4. ed. São Paulo: Saraiva, 2012. v. 4.

COMPARATO, Fábio Konder. Nótula sobre o Direito à Comunicação Social. In: CAVALCANTI FILHO, José (Org.). Informação e poder. Rio de Janeiro: Record; Recife: Fundação de Cultura Cidade do 
Recife, 1994. p. 67.

EPPLE, Cristiane et al. A evolução histórica do direito de Autor. In: REIS, Jorge Renato et al. (Org.). Estudos de direito de autor no constitucionalismo contemporâneo. São Paulo: Multideia, 2011.

GANDELMAN, Henrique. De Gutemberg à Internet: direitos autorais na era digital. 4. ed. Rio de Janeiro: Record, 2001.

JENKINS, Henry. Cultura da Convergência. 2. ed. São Paulo: Aleph, 2009.

LESSIG, Lawrence. Free culture. 2002. Disponível em: $<$ http:// archive.oreilly.com/pub/a/policy/2002/08/15/lessig.html >. Acesso em:1 jun. 2017.

\section{LIMA, Venício A. Liberdade de expressão $\mathbf{x}$ liberdade da} imprensa: direito à comunicação e democracia. 2. ed. São Paulo: Publisher, 2012.

MACHADO, Jorge. Desconstruindo "propriedade intelectual”. Observatório, São Paulo, v. 4, p. 245275, 2008. Disponível em: <http://www.google.com. $\mathrm{br} / \mathrm{url}$ ?sa $=\mathrm{t} \& \mathrm{rct}=\mathrm{j} \& \mathrm{esrc}=\mathrm{s} \&$ source $=$ web\&cd $=1 \& \mathrm{ved}=$ 0ahUKEwiSvrquyujUAhVQlpA KHRqcBfAQFggjMAA\&url=http\%3A\%2F\%2Fobs.obercom. pt $\% 2$ Findex.php $\% 2$ Fobs $\% 2$ Farticle $\% 2 F d o w n l o a d \% 2 F 92 \% 2 F 139 \&$ usg=AFQjCNF-4Mq9Ar2wHHPdu4upJdOVuunWkg $>$ Acesso em: 1 jun. 2017.

PIRES, Eduardo; BOFF, Salete Oro. A função social do direito de Autor. In: REIS, Jorge Renato et al. (Org.). Estudos de direito de autor no constitucionalismo contemporâneo. São Paulo: Multideia, 2011.p. 105. 
MONCAU, Luiz Fernando Marrey. Liberdade de expressão e direitos autorais. Rio de Janeiro: Elsevier, 2015.

SOUZA, Juliana Barros de. Fanfiction como recurso de letramento e cultura. Revista Encontros de Vista, Recife, n.14, jul./dez. 2014. Disponível em: <http://www.encontrosdevista.com.br/Artigos/4-20142.pdf> Acesso em: 1 jun. 2017.

THOMPSON, Jonh B. A mídia e a modernidade: uma teoria social da mídia. 7. ed. Petrópolis, RJ: Vozes, 2005.

UNESCO. Many voices, one world: towards a new more just and more efficient world information and communication order. New York: United Nations Education, Scientific and Cultural Organization, 1980. Arquivo PDF disponível em: < http://unesdoc.unesco.org/ images/0004/000400/040066eb.pdf $>$ Acesso em: 23 de agosto de 2016.

ZANINI, Leandro Estevam de Assis. Direito de autor. São Paulo: Saraiva, 2015.

ZAPPONE, Mirian H. Y. Fanfics: um caso de letramento literário na cibercultura? Revista Letras de Hoje, Porto Alegre, v.43. n. 2, 2008. Disponível em: $<$ http://revistaseletronicas.pucrs.br/ojs/index.php/fale/article/ view/4749/3578>. Acesso em: 1 jun. 2017.

Como citar: AMARAL, Jordana Siteneski do; BOFF, Salete Oro. Uma obra e vários autores: o direito autoral e as "fan-fictionals" na cultura da convergência. Scientia Iuris, Londrina, v. 22, n. 1, p.162-189, mar. 2018. DOI: $10.5433 / 2178-8189.2018 v 22 n 1 p 162$. ISSN: $2178-8189$

Recebido em: 16/07/2017

Aprovado em: 05/09/2017 